\title{
Assessing the Role of Infiltration Galleries to Enhance Groundwater Recharge in Model Town Lahore
}

\author{
Muhammad Fahim Aslam ${ }^{1, ~ *, ~ H a b i b-u r-R e h m a n ~}{ }^{2}$, Noor Muhammad Khan ${ }^{1}$ \\ ${ }^{1}$ Centre of Excellence in Water Resources Engineering, University of Engineering and Technology, Lahore, Pakistan \\ ${ }^{2}$ Department of Civil Engineering, University of Engineering and Technology, Lahore, Pakistan
}

Email address:

engr_fahim@outlook.com (M. F. Aslam)

${ }^{*}$ Corresponding author

\section{To cite this article:}

Muhammad Fahim Aslam, Habib-ur-Rehman, Noor Muhammad Khan. Assessing the Role of Infiltration Galleries to Enhance Groundwater Recharge in Model Town Lahore. American Journal of Water Science and Engineering. Vol. 7, No. 1, 2021, pp. 14-23.

doi: 10.11648/j.ajwse.20210701.12

Received: November 13, 2020; Accepted: November 30, 2020; Published: March 12, 2021

\begin{abstract}
Lahore is the provincial capital of Punjab and second biggest city of Pakistan with respect to the population. Average annual population growth of Lahore is 4.14\% from 1998-2018, which is much higher than the average population growth rate of Pakistan which is $2.4 \%$. According to investigations average annual groundwater depletion rate of Lahore is $1.07 \mathrm{~m} /$ year. As with the growth of population new housing societies are being built to accommodate the burgeoning population. These societies enhance impermeable areas, moreover, pump huge amount of groundwater from the underground water source. There should be sustainability in water pumping and water recharging. Past studies show that groundwater exploitation in Lahore is not sustainable as abstraction rates are higher as compared to groundwater recharge rates. Therefore it is necessary of find out alternative means to recharge the groundwater aquifer of Lahore. There is a need to investigate the role of infiltration galleries to accelerate the groundwater recharge. In order to complete the research, temporal distribution was plotted on ArcMap. HEC-HMS was used for the calculation of discharges which were verified with analytical methods. Groundwater model prepared on Visual MODFLOW was calibrated and validated. The results indicate that due to groundwater overexploitation water levels continue to decrease with the passage of time. The average simulated water table decline is 1.1 meter per year in the study area. So in order to overcome this crisis, infiltration galleries were proposed and designed in the study area. It was seen that these infiltration galleries allow recharging the groundwater at better rate. As the model results showed that depletion rate of groundwater reduces and the groundwater level is about $0.3 \mathrm{~m}$ higher when there are infiltration galleries. The study proposes that the Infiltration Galleries have a potential to recharge the groundwater at good rate, therefore its installation must be preferred according to the groundwater hydrological balance in the region.
\end{abstract}

Keywords: Aquifer, Hydrological Balance, Infiltration Galleries, Depletion Rate, Recharging

\section{Introduction}

Groundwater is one of the most treasured and widely distributed natural water resources, which constitutes the largest available source of water for water supply and irrigation in semi-arid regions. Only $2.8 \%$ of total water available is fresh water on the earth. From this $2.8 \%, 2.2 \%$ is surface water and $0.6 \%$ is ground water, which is available beneath the earth's surface. Out of the $0.6 \%$ the water available within $800 \mathrm{~m}$ depth can be economically extracted using the present drilling technology. This accounts to $0.3 \%$ of the total ground water. More than $90 \%$ of our rural population depends on groundwater. Nowadays, the depletion of groundwater is undergoing a rapid increment for meeting the water needs of increasing population. So, it is important to analyze and predict the future trends in groundwater flow.

Groundwater is an important water resource due to its good quality, easy accessibility, and little seasonal shifts. For arid and semi-arid areas just like Pakistan, it becomes the major source of water for the public. Non sustainable and non-ecofriendly human actions on the environment have intensified which is the primary cause of the impact on the groundwater level in certain locations. Rapid increase in population also demands more food and utilities 
for their livelihood. In order to acquire more cropping intensity water requirement for irrigation has also increased resulting in excessive pumping. Growing population results in pumping water from groundwater aquifer for domestic and industrial use. Moreover rapidly increasing industrial units and factories in the urban areas also demand more water for their operations. More cropping intensity, domestic and industrial purposes water requirements is collectively imposing stress on groundwater aquifer. While on the other hand, natural groundwater recharging sources are declining due to urbanization, climate change, poor management and planning which has increased the gap between recharge and abstraction in the area.

Lahore is provincial capital of the Punjab province. Also it is $2^{\text {nd }}$ biggest city of Pakistan with respect to the population. Average annual population growth of Lahore is $4.14 \%$ from 1998-2017, which is much greater than the average population growth rate of Pakistan which is $2.4 \%$ [3]. The population of Lahore increased from 5,143,495 persons in 1998 to $11,126,285$ persons in 2017 showing $53.77 \%$ rise in population in last twenty years. Current population density of Lahore is 6300 persons $/ \mathrm{km}^{2}$ [3]. With the increase in the population, the covered/paved area of the city is increasing due to the construction of residential and commercial structures, reducing the infiltration of water in ground. Due to which groundwater recharge is depleting.

Lahore city uses water for all the purposes such as for domestic, commercial and industrial activities which are increasing at an alarming stage. To overcome the scarcity of surface water, WASA abstracts 280 to 290 million gallons/day of groundwater from the underground aquifer. Private sector is also abstracting considerable amount of groundwater, which is approximated at 150 million gallons per day [16]. The water supply to the city of Lahore is totally dependent on the maintenance of aquifer under Lahore region.

495 tubewells are operated by WASA while 193 tubewells of capacity varying from 2 to 4 cusecs are operated by cantonment, residential societies and industries in Lahore. This extensive abstraction of groundwater is depleting the water table at an average rate of $1.07 \mathrm{~m} /$ year [7]. According to investigations carried out by [13] the average annual groundwater depletion rate of Lahore is $1.27 \mathrm{~m} /$ year. This rate of recession is alarming and will lead to water shortage in near future depriving us from the underground source of water.

The per capita water availability in Pakistan at the time of independence was 5,600 cubic meters, which has been decreased by over 406 percent from 5,260 cubic meters in 1951 to 1,038 cubic meters in 2010 . If the status quo continues, then it will further decrease to 660 by year 2025 and will further go down to an alarming level of 575 cubic feet in 2050 keep in view the population explosion. [14]

Lahore Development Authority (LDA) has prepared any comprehensive regulations for recharging the aquifer through domestic and department level. It has banned to connect the water from roofs to directly into sewer. They have made mandatory for houses bigger than $380 \mathrm{~m}^{2}$ to build a recharge well/recharge pit in their premises. They have also asked the park owners and agencies to prepare a rain harvesting plan and implement it in true accordance. They have given the responsibilities for the operation and maintenance of rain water harvesting to respective departments [9]. They have also provided the details of water usage for both domestic and industrial levels. But due to their non-implementation of policies people are using according to the requirements without knowing the gravity of the problem. Housing societies are not taking any measures to construct recharge trenches or pits.

As with the growth of population new housing societies are being built to accommodate the burgeoning population. These societies are launched without any detailed design and basic requirements. One among them is groundwater studies in the society areas. These societies pump huge amount of groundwater from the underground water source and do nothing for recharging of the aquifer. No body considers groundwater hydrology balance before launching a society. There should be means and base so that minimum imbalance takes place. There should be sustainability in water pumping through groundwater recharging.

There are number of sources through which groundwater can be recharged artificially. Some of them are permeable pavements, rain gardens, vegetative swales, infiltration galleries, green roofs and planter boxes.

Various studies have been done on the working of infiltration galleries to study their impact on reducing urban flooding and helping in recharging the groundwater aquifer. Infiltration trench prevented up to $95 \%$ of the runoff in the area [1]. Results obtained through comparison of two galleries one constructed of crushed graded gravel while the other using an engineered leach drain system (Atlantis Leach System) revealed that Atlantis infiltration gallery successfully infiltrated $17 \mathrm{ML}$ of treated wastewater [5]. Infiltration Trench can allow $90.4 \mathrm{ft}^{3}$ of water to infiltrate into the soil [17]. Trench infiltration is a promising alternative technique for increasing recharge and minimizing evaporation [19]. L. Amount of rainwater that can be recharged with the help of infiltration trenches is $11,550 \mathrm{~m}^{3} /$ annum in Dhaka [10]. Experimental study on an installed infiltration trench showed a minimum capacity of infiltrating $63.57 \%$ of the input volumes, presenting it as a compensatory technique in the management of urban rainwater [11]. The use of infiltration trenches in Subdivision 1 resulted in a 77\% reduction in peak discharge and a $98 \%$ reduction in storm water volumes in Subdivision 2 [15]. Gravel trench tended to have the highest peaks and responded to more storms while studying the behavior of runoff mitigations [8]. Infiltration galleries can control quality and quantity of storm water [2].

Therefore it is necessary of find out alternative means to recharge the groundwater aquifer of Lahore. From the artificial sources to recharge the groundwater, role of infiltration galleries was opted to check their role in accelerating the groundwater recharge.

\section{Theoretical Background}

\subsection{Study Area}

The study area was Model Town Cooperative Housing 
Society, Lahore. The coordinates of the study are $31^{\circ} 29^{\prime} 5^{\prime \prime} \mathrm{N}$, 74¹9'47" E situated just next to Kalma Chowk. It is the oldest cooperative housing society of Lahore spread over an area of 592 hectares. Map of Model Town in shown in Figure 1 and the area distribution is shown in Table 1.

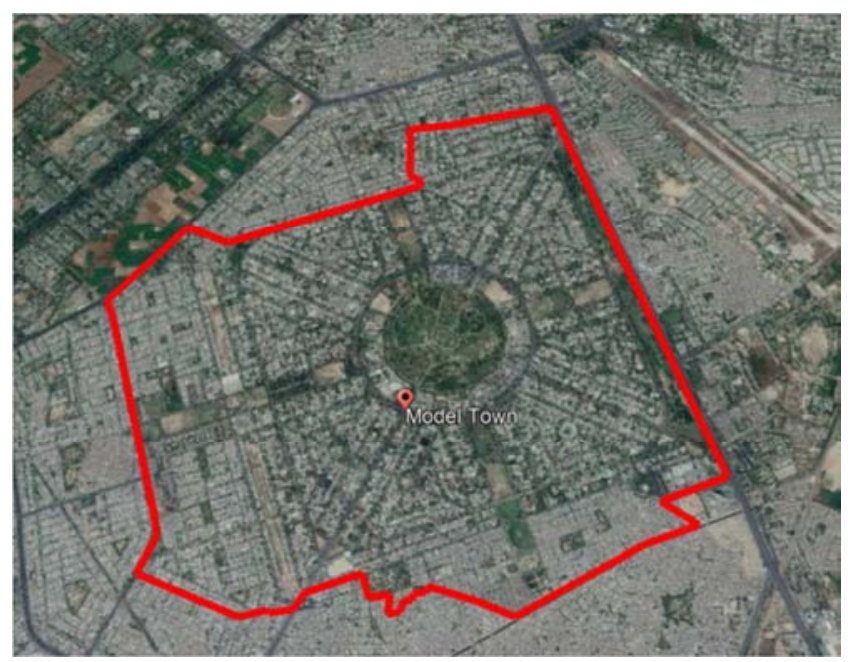

Figure 1. Map of Model Town Lahore (Google Earth 12-10-19).

Table 1. Land type of study area.

\begin{tabular}{llll}
\hline S. No. & Type of Land & Area $(\mathbf{H a})$ & \% age Area \\
\hline 1. & Residential & 331.4 & 56 \\
2. & Commercial & 11.7 & 2 \\
3. & Roads & 112.5 & 19 \\
4. & Nurseries and playgrounds & 23.9 & 4 \\
5. & Green area (parks) & 112.5 & 19 \\
6. & Total Area & $592 \mathrm{ha}$ & 100 \\
\hline
\end{tabular}

\subsection{Climate}

Lahore experiences extremes of climate. The summer season starts in April and continues till September. The hottest months are May, June and July. The mean maximum and minimum temperature during these months vary between $40.4^{\circ} \mathrm{C}$ and $27.4^{\circ} \mathrm{C}$. The winter season lasts from November to March. The coldest months are December, January and February with minimum temperature reaching up to freezing point. The mean maximum and minimum temperature during this period are $22^{\circ} \mathrm{C}$ and $5.9^{\circ} \mathrm{C}$.

Rainfall varies from year to year and from month to month. Maximum rainfall however, occurs in July and August when the monsoon depression travels westward. Precipitation is lowest in November, with an average of $4 \mathrm{~mm}$. Most of the precipitation falls in July, with an average of $189 \mathrm{~mm}$.

\subsection{Objectives}

1. To analyse the temporal distribution of groundwater levels in the study area.

2. To assess the average groundwater depletion rates based on past data.

3. To investigate the future groundwater depletion rate.

4. To propose/design Infiltration Galleries for Model Town.

5. To study the impact of proposed Infiltration Galleries on groundwater recharge rate.

\subsection{Methodology}

\subsubsection{Data Collection}

Historical data of several parameters like rainfall, land use and runoff were required for this study, which is the record of the past data for many years. These historical data were necessary to compare the past and present conditions of different parameters to assess their trends/patterns with the passage of time. Data collected for the research work is shown in Table 2.

Table 2. Data collected for research work.

\begin{tabular}{lll}
\hline Data Description & Source of Data & Data Period \\
\hline Groundwater Elevations & WASA & $1991-2018$ \\
Rainfall & PMD & $1981-2018$ \\
SRTM $(30 \mathrm{~m})$ & srtm.csi.cgiar.org & 2018 \\
Borehole log Data & IEER UET & 2018 \\
Topographical Data & Google Earth & 2019 \\
\hline
\end{tabular}

\subsubsection{Data Analysis}

The data was analyzed, verified and digitized for further processing in the calculations and models.

\subsection{Watershed Delineation Using Arc Hydro Tools}

The first step in doing any kind of hydrologic modeling involves delineating streams and watersheds, and getting some basic watershed properties. Using digital elevation models (DEM) and GIS tools, watershed properties and terrain processing was carried out. Arc Hydro tools were used to process a DEM in order to delineate watershed and stream networking that describe the drainage patterns of study area. Water Shed Delineation is shown in Figure 2.

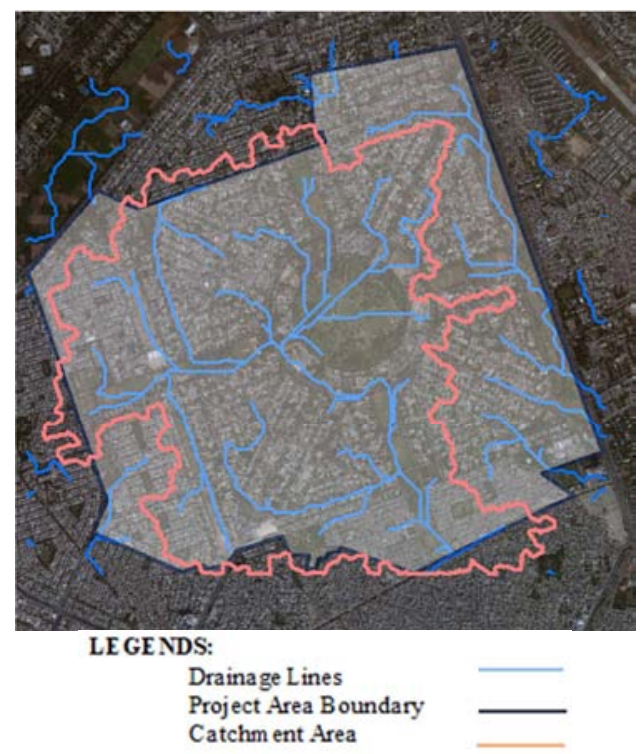

Figure 2. Watershed delineation.

\subsection{Model Description}

\subsubsection{HEC-HMS}

For discharge calculation, HEC-HMS which is open source software for the modeling of the rainfall-runoff process was used. Model components/inputs comprises of the 
basin model manager, meteorological model manager, control specifications manager, time series data manager [18]. The runoff quantity was obtained by SCS Curve Number Method through HEC HMS Model Simulation. Data related to the size of area, curve number, lag time and time of method was selected in the basin model manager. Gauge data was selected in the meteorological model manager. In the control specifications manager the time period of the rainfall data was entered. Start and end time along with time interval was selected. While in the time series data manager the complete data was entered in the tabular format.

The model was calibrated and verified for the study area by using the rainfall event in the current time period. The calculated discharge from the model was compared with the discharge calculate with the simple analytical method using the Manning equation shown in Figure 3. As there was no discharge measuring structure in the study area therefore the previous flood marks were taken for the calculation of discharge.

$$
Q=A \frac{1}{n} R^{\frac{2}{3}} S^{\frac{1}{2}}
$$

Where $\mathrm{Q}$ is discharge, $\mathrm{A}$ is area, $\mathrm{R}$ is the hydraulic radius, $\mathrm{n}$ is roughness co-efficient and $\mathrm{S}$ is slope.

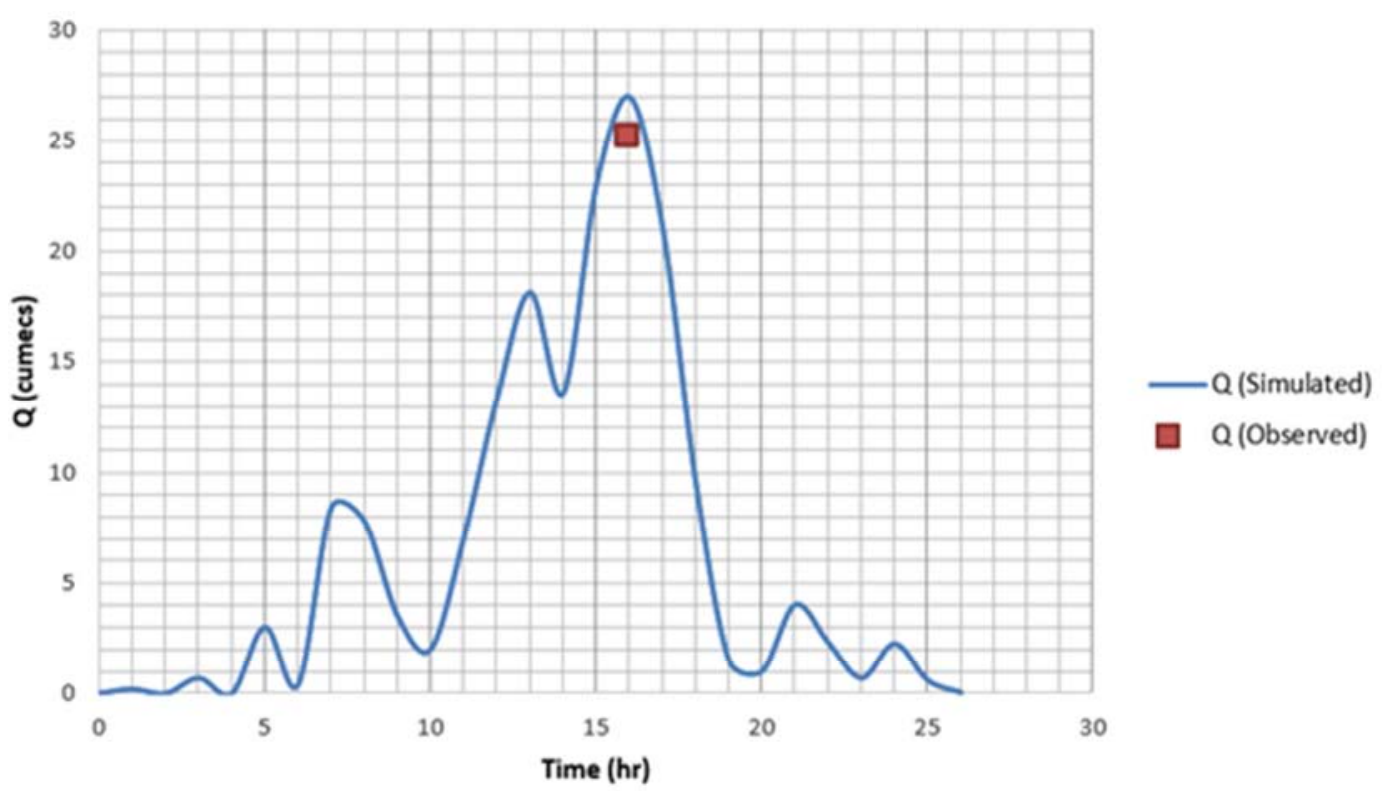

Figure 3. Comparisons of discharges from model and site.

\subsubsection{Visual MODFLOW}

In this study, a three- dimensional finite difference modelling program namely Visual MODFLOW 2011.1 was used for the study and prediction of aquifer. The base map of the study area, various layers of the geological strata and their geological properties, boundary conditions, well data and recharge conditions were fed in to the model as inputs. The model was then calibrated and validated, after which future groundwater conditions were predicted.

Microsoft Excel was also used for input data preparation and the data were exported to visual MODFLOW using the import elevation command. Following steps were carried out to prepare the model.

\section{i. Setting up of Visual MODFLOW Model}

Visual MODFLOW supports the use of base maps in all modules of the program. The base map of the study area was imported into the model and was set according to the coordinate system. The model is based on a rectangular block- centered grid network covering the entire model domain. For, this proper cell size was chosen in order to avoid any type of interpolation while importing the topographic map. Visual MODFLOW requires model data to be entered in consistent units; selected units were meters and day, and for recharge $\mathrm{mm} / \mathrm{y}$ was used.

ii. Hydrogeological Characterization

The model must be prepared according to the proper characterization of the hydrogeological conditions at site. Without proper site characterization, it is not possible to select an appropriate model or develop a reliably calibrated model. The input parameters include model grid size and spacing, layer elevations, boundary conditions, hydraulic conductivity/transmissivity, recharge, any additional model input, transient or steady state modelling, dispersion coefficients, degradation rate coefficients etc.

iii. Importing Elevation

Surface elevation and bottom elevation data of the aquifer was added in the model.

iv. Ground Elevations Data

Elevations of the study area were taken from the Google earth and the kmz file was prepared containing number of points and it was then converted into excel file using TCX converter software. TCX Converter was used to convert the elevations of the area from $\mathrm{kmz}$ file into a csv excel file. This file was used in the Visual MODFLOW software for the natural surface level of the study area. 


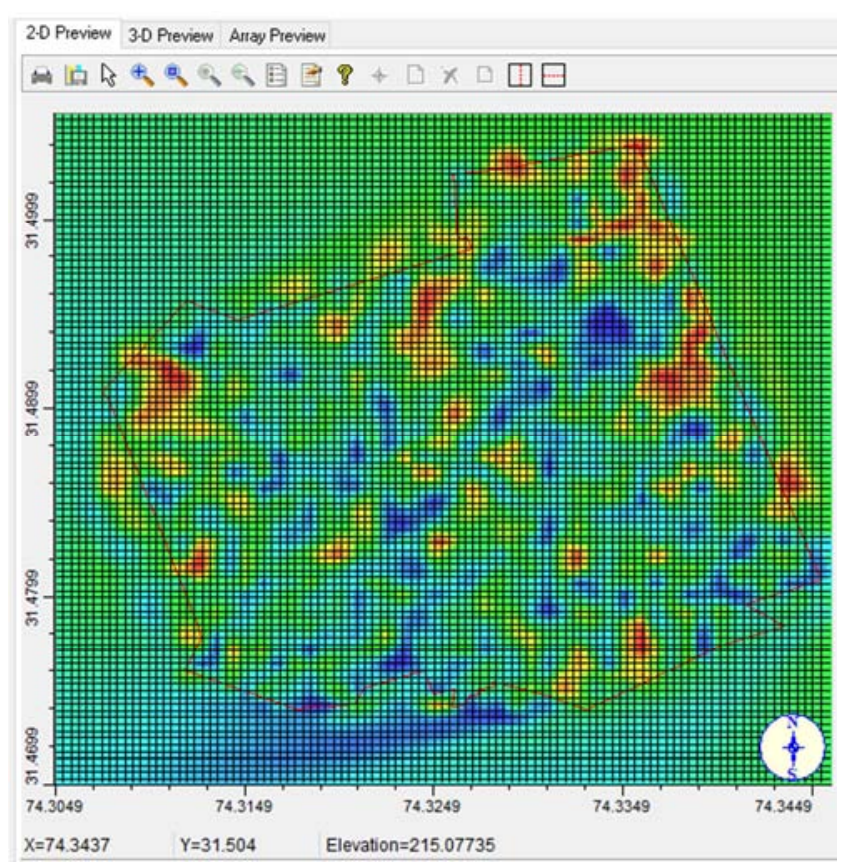

Figure 4. Imported elevations of study area.

\section{v. Adding Wells}

The data of the groundwater level elevations from the observation wells was prepared in the excel sheet which were than imported into the software. A total of 19 observation wells data was entered in the model.

vi. Adding Properties

The hydraulic conductivity values for the layer were added. vii. Adding Boundaries

The boundary conditions represent the systems relationship with the surrounding areas. General Head Boundary condition was considered from all the sides. There is no water body adjacent to the area therefore no river head boundary condition was considered. Also the area is not isolated from any side therefore no constant head boundary condition was taken.

viii. Recharge

The recharge package is designed to simulate aerial distributed recharge to the groundwater system of the study area. Mostly, the aerial recharge occurs by the precipitation that percolates into the groundwater system. So the data of the rainfall runoff was used as input for the recharging of the groundwater table elevation.

\section{ix. MODFLOW Run}

After entering all the input parameters, the model run command was carried out for the transient state condition of the study area. Initial head options, recharge options, WHS Solver parameters, anisotropic factor, layer type and rewetting options were also selected appropriately.

x. Model Calibration

Model Calibration is task of modification of model input data in its most limited meaning in order to make the model more accurate. Through this way, model depicts closer values of observed heads, water levels and flow conditions. The model was calibrated for transient state for the data of year 2000 to 2008. A model which is calibrated takes selected values from hydrogeological parameters, sources and sinks and boundary conditions which then help to match the existing field scenarios. With the help of changing conductivity values the calibration curve is plotted. The complete graph comprising of computed along with observed head values for selected observation wells are shown in Figures 5. This figure proposes that there is a very good relationship among the calculated and observed water levels in majority of the wells. All the points are plotted very closely to each other and they are in the $95 \%$ confidence interval lines which mean that the model is calibrated.

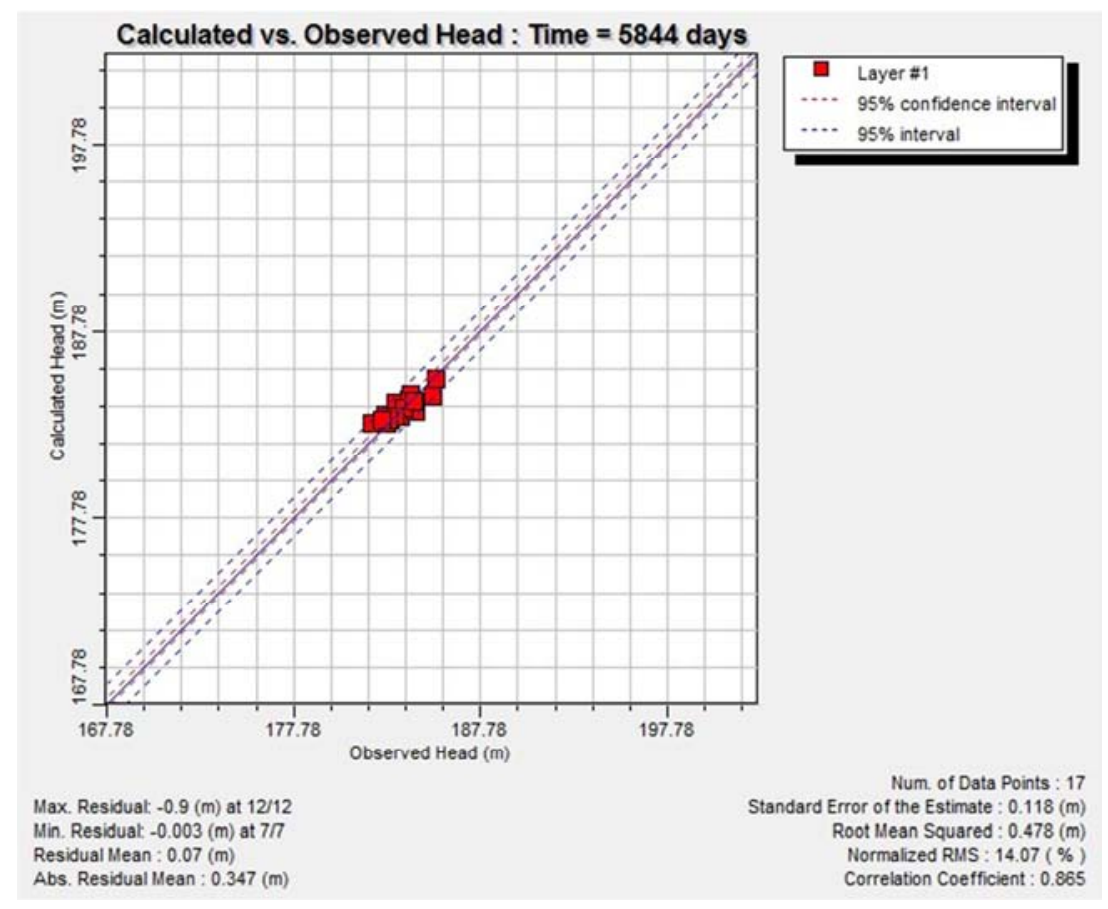

Figure 5. Calibrated values of head in the model. 


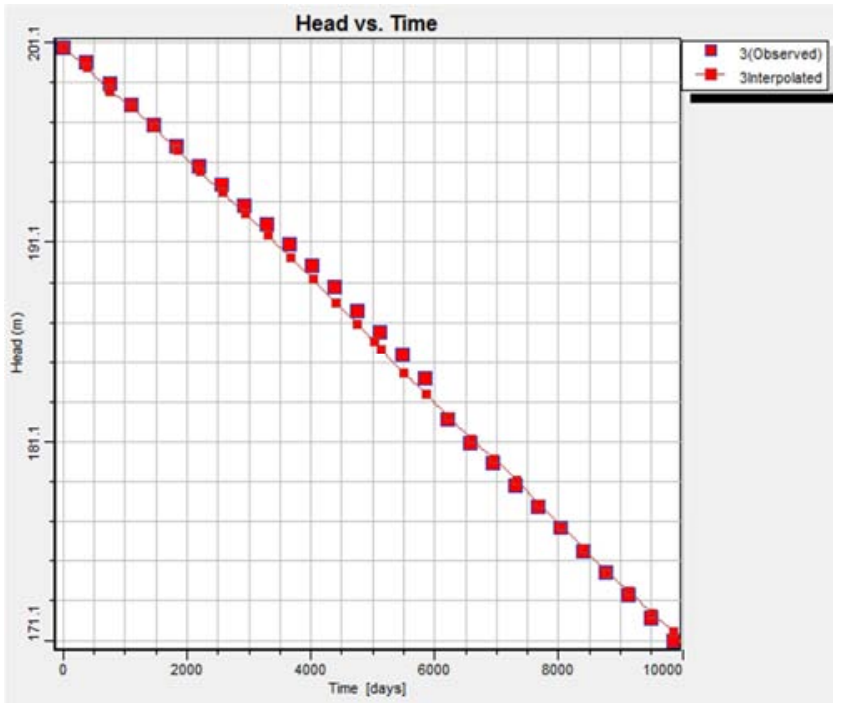

Figure 6. Validated model.

xi. Model Validation

Following calibration, the groundwater flow model was validated with data. The process of model verification may result in further calibration or refinement of the model. Validation was done for the data of 2010 to 2016. It was observed that the water table values of the validated model were matching with the calculated values. After the model has successfully reproduced measured changes in field conditions, it was ready for predictive simulations. Model verification helps to predict the future scenarios accurately. From the Figure 6, it is evident that model was well validated for each stress period as all the values in each graph lie within $95 \%$ confidence interval with correlation coefficients as 1 . Table 3 depicts the statistical checks for the calibration and validation of model.

Table 3. Statistical checks for model.

\begin{tabular}{lll}
\hline Description & Value & Range \\
\hline Mean Square Error & 0.17 & Close to zero \\
Root MSE & 0.52 & $<0.7$ \\
$\mathrm{R}^{2}$ & 0.84 & $0.7-0.9$ \\
\hline
\end{tabular}

\subsection{Design of Infiltration Galleries}

Infiltration galleries are shallow between 1 to $3 \mathrm{~m}$ deep rock-filled excavations that serve as reservoirs for storm water runoff. Potential routes/locations for Infiltration Galleries (IG) were demarcated usually at low line areas such as parks, playing fields, green belts along the roads etc. using the DEM of Model Town on ArcGIS software. Design of Infiltration galleries comprising of bed width, depth and filter material was carried out with respect to the amount of storm water runoff generated [12]. Figure 7 shows the typical cross section of infiltration gallery.

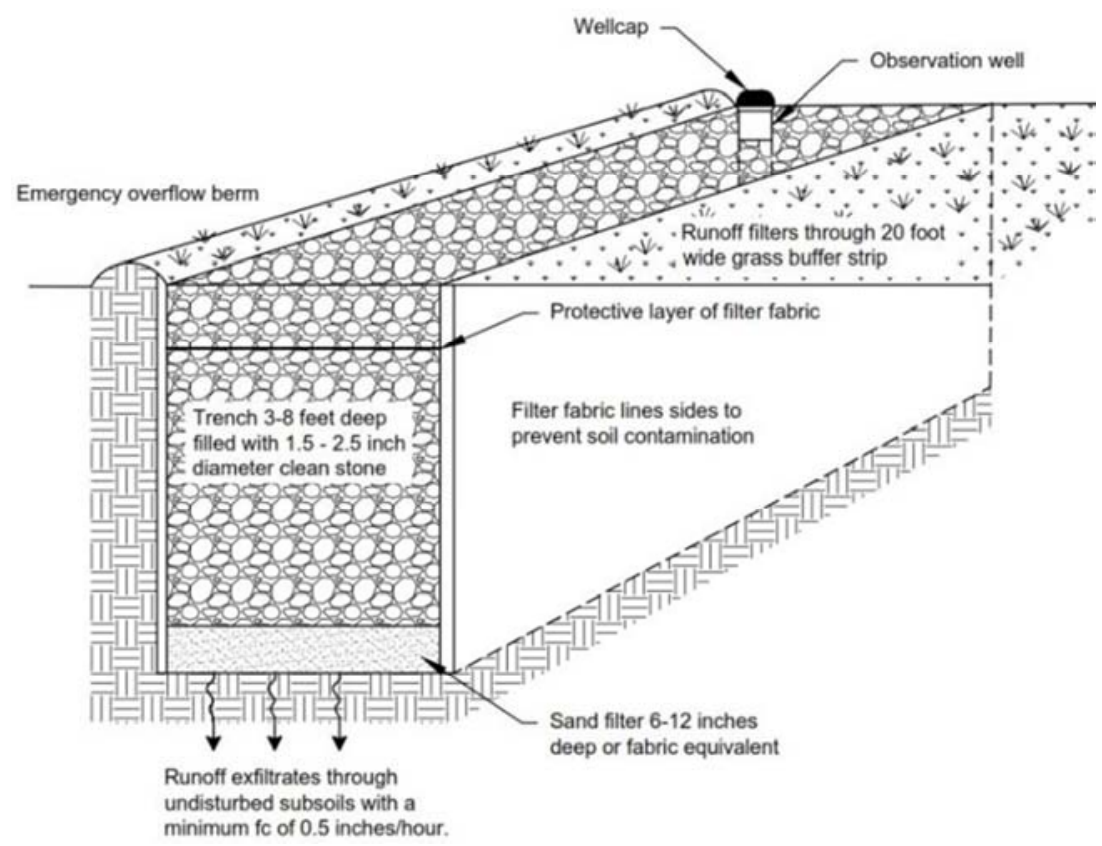

Figure 7. Infiltration gallery [4].

The following criteria must be considered as minimum standards for the design of an infiltration gallery facility.

\subsubsection{Location and Siting}

To be suitable for infiltration, underlying soils should have an infiltration rate (fc) of $12 \mathrm{~mm}$ per hour or greater, as initially determined from NRCS soil textural classification and subsequently confirmed by field geotechnical tests. Soils on the drainage area tributary to an infiltration gallery should have a clay content of less than $20 \%$ and a silt/clay content of less than $40 \%$ to prevent clogging and failure. The minimum geotechnical testing is one test hole per 450 square meters, with a minimum of two borings per facility. Infiltration galleries cannot be constructed in fill soils. It is recommended that contributing drainage area of Infiltration galleries should be 2.5 hectare or less. The infiltration 
galleries must be $3 \mathrm{~m}$ away from a property line, $7 \mathrm{~m}$ from a building foundation, $30 \mathrm{~m}$ from a private well/ septic system tank/leach field and other sources of water [6].

When used in an off-line configuration, the water quality protection volume (WQv) is diverted to the infiltration gallery through the use of a flow splitter. Stormwater flows greater than the $\mathrm{WQv}$ are diverted to other controls or downstream using a diversion structure or flow splitter.

To reduce the potential for costly maintenance and/or system reconstruction, it is strongly recommended that the gallery be located in an open or lawn area, with the top of the structure as close to the ground surface as possible. Infiltration galleries shall not be located beneath paved surfaces, such as parking lots.

\subsubsection{Design Steps}

Infiltration galleries were designed with follow design steps.

Amount of Infiltrated Storm Water was calculated with the equation below

$$
Q_{p}=\frac{C_{s} C_{r} I A}{360}
$$

Where, Qp is peak discharge (cumecs), A is the catchment area (ha), $\mathrm{Cs}=$ storage coefficient $(0.7)$ and $\mathrm{Cr}$ is runoff coefficient (0.4)

Rainfall Intensity was determined through following equation.

$$
i_{d, t}=\frac{69.536-23.457\left(\ln \left(-\ln \left(1-\frac{1}{T}\right)\right)\right)}{d^{0.686}}
$$

Retention Time in the infiltration gallery was calculated as

$$
D=\frac{P \times t}{n \times 12}
$$

Infiltration Gallery area was calculated with the help of equation.

$$
A=\frac{12 \times V}{P \times n \times t}
$$

\subsubsection{Additional Maintenance Considerations and Requirements}

A record should be kept of the dewatering time of an infiltration gallery and timely removal of sediment and media must be done. The aggregate material for the gallery should be well graded consisting of a clean aggregate with a maximum diameter of $75 \mathrm{~mm}$ and a minimum diameter of 40 $\mathrm{mm}$. A 6-inch layer of clean, washed sand must be placed on the bottom of the gallery to encourage drainage and prevent compaction of the native soil, while the stone aggregate is added. The aggregate should be completely surrounded with an engineering filter fabric. The observation well should consist of perforated PVC pipe, 100 to $150 \mathrm{~mm}$ diameter, located in the center of the structure.

\subsubsection{Selection of Locations for Infiltration Galleries}

Proposed locations for installing of the infiltration galleries were selected shown in Figure 8. The location points comprises of depression points in the study area, green belts along roads, sides of parks and parking lots.

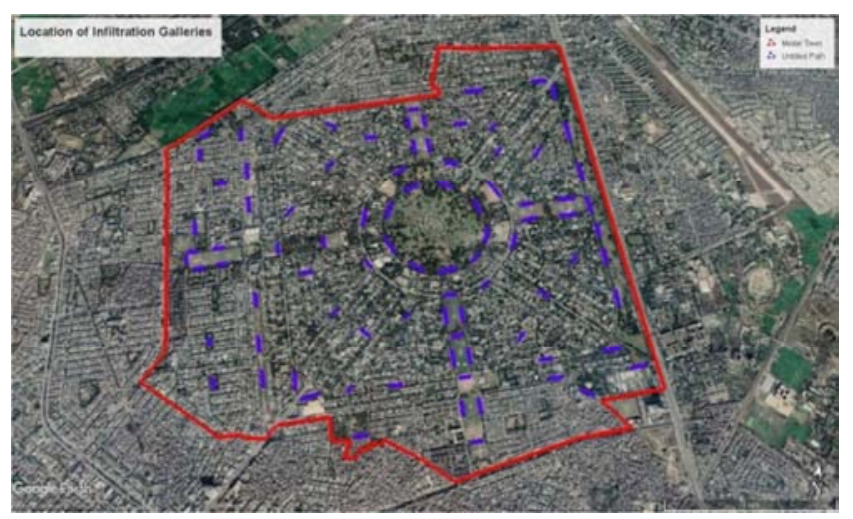

Figure 8. Proposed locations of infiltration galleries.

\section{Results and Discussion}

\subsection{Temporal Distribution of Rainfall}

Temporal distribution of rainfall data used for the research from year 1981 to 2018 was plotted. Maximum monthly rainfall value was used for this purpose. Figure 9 depicts the temporal distribution in the form of bar chart. Average value of the rainfall is also shown.

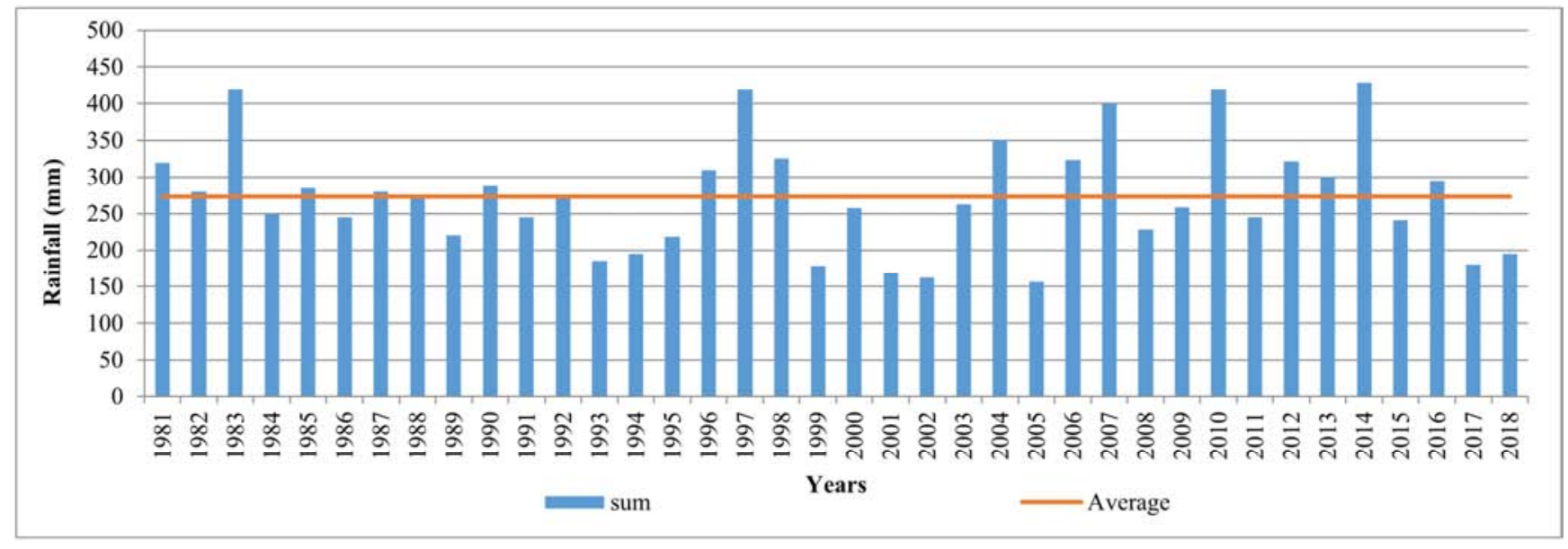

Figure 9. Temporal distributions of rainfall data. 


\subsection{Abstraction Rates of Pumps}

There are total 19 pumping wells in the research area which are used to meet the demand of water usage in the study area. These pumps are operated usually for 12-14 hours during winter season while 16-20 hours during the summer season.

Mean annual extraction of groundwater from the study area is around $2,120,775 \mathrm{~m}^{3}$.

\subsection{Groundwater Depletion Rate}

The groundwater depletion rate was estimated for the available data of groundwater levels. Figure 10 shows the plot of groundwater depletion rates in the study area plotted for the average depletion rates for all the wells. Also temporal distribution from nineteen wells used for pumping of groundwater in the study area is plotted to get the trend of the groundwater depletion scenario. It is visible from the plot that for all the wells the groundwater levels has reduced every year due to excessive pumpage of groundwater.

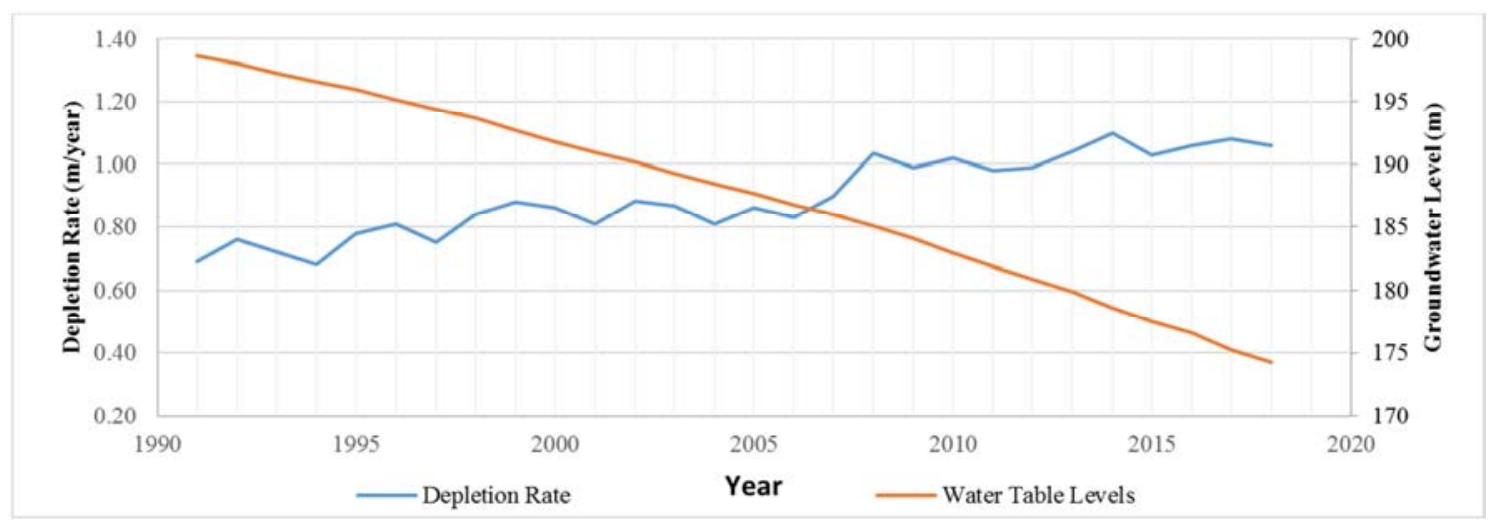

Figure 10. Temporal distribution of pumping wells.

\subsection{Temporal Distribution of Groundwater}

The groundwater depletion rate was estimated for the available data of groundwater levels. It was found that the groundwater is depleting at alarming level. The groundwater is depleting at an annual rate of 1 meter in the study area. The temporal distribution curves plotted against the time periods for the study area are shown in Figure 11 and Figure 12.
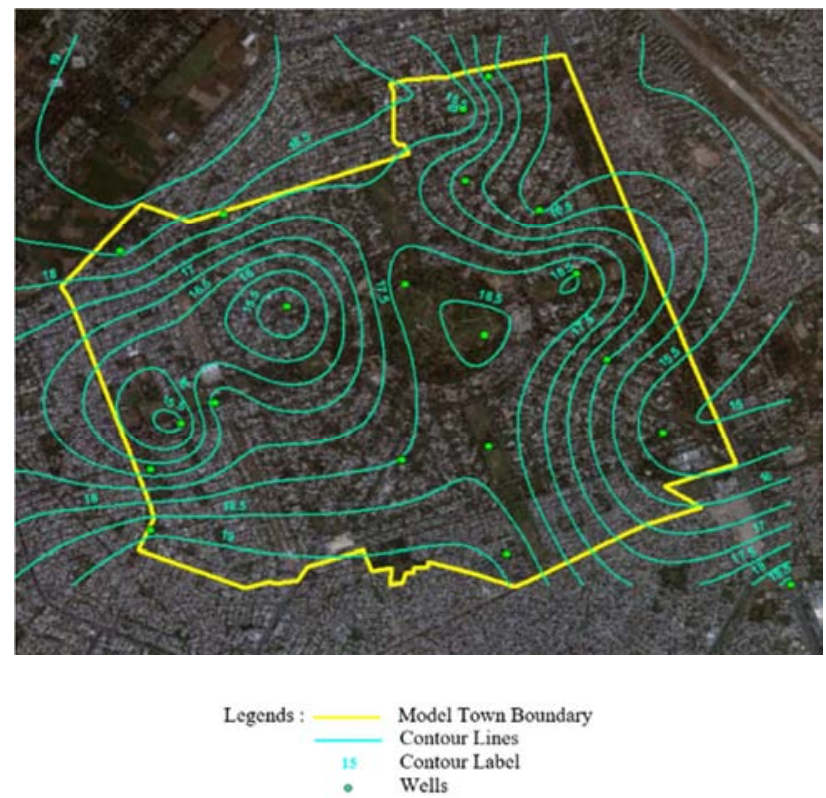

Figure 11. Temporal distributions of groundwater elevations data (Year 1991).
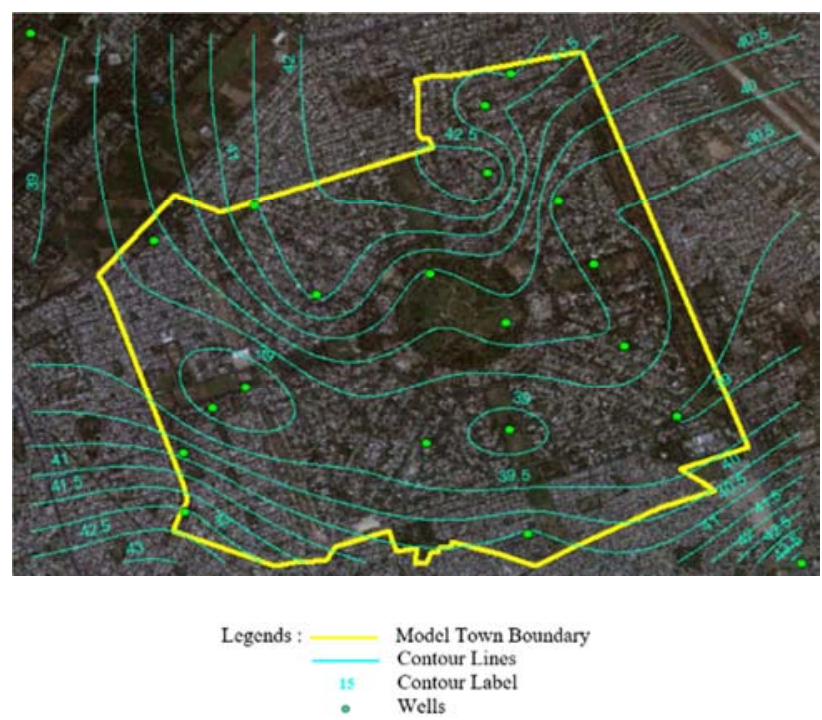

Figure 12. Temporal distributions of groundwater elevations data (Year 2018).

Previously held studies regarding groundwater depletion rates in Lahore also revealed that the groundwater is depleting at a rate of $1.07 \mathrm{~m} /$ year [7] and $1.27 \mathrm{~m} /$ year [13]. This proposes that the depletion rate in the complete Lahore city is depleting at more than $1 \mathrm{~m} /$ year.

\subsection{Future Depletion Rate of Groundwater Without Infiltration Galleries}

The model prepared on Visual MODFLOW was calibrated and validated to get the best results. 
After carrying out the procedure of calibration and validation the model was then simulated for the future years to get the depletion rate in future without the placement of infiltration galleries in the study area. The groundwater depletion rate was estimated for the future five (5) years. It was found that the groundwater would deplete at a rate of 1.1-1.2 meters for next five years.
Model results of every stress period were exported to excel sheet to calculate average groundwater elevation. Difference between these average groundwater elevation values of every two adjacent stress periods gave the depletion rate between them. This was carried out for all the stress periods. Average annual depletion rate for the complete study area was calculated from the depletion rates from different locations.

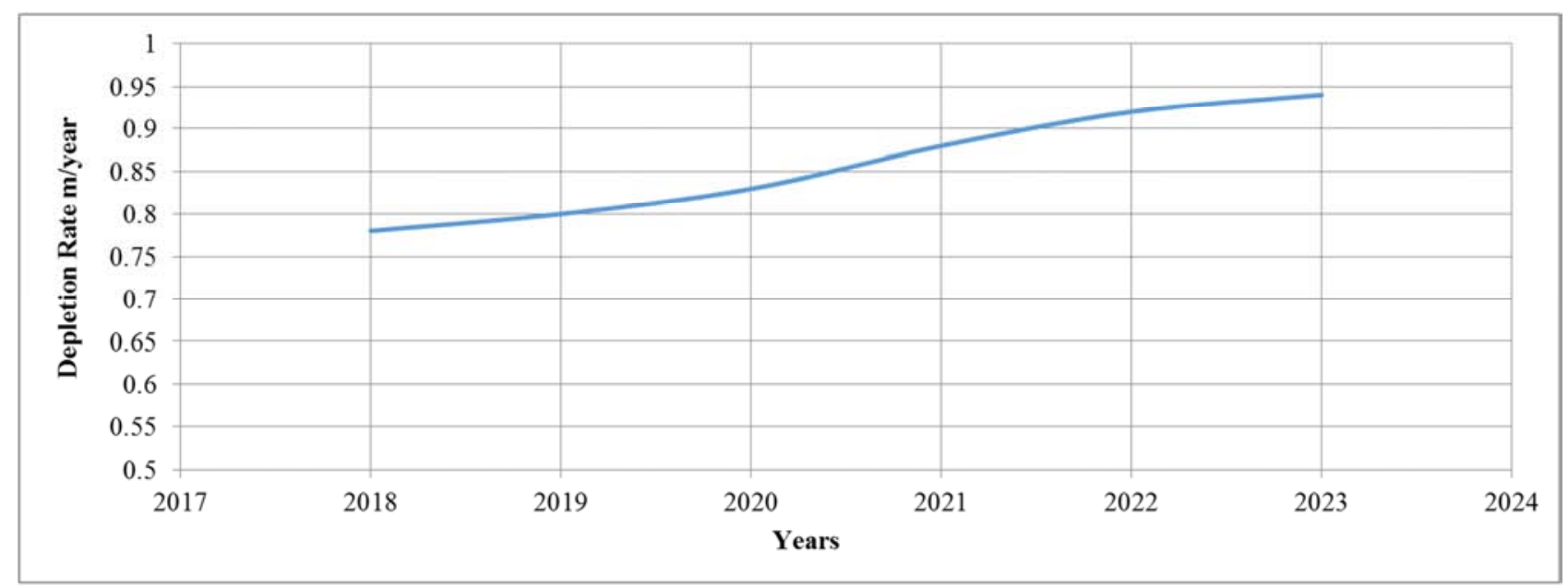

Figure 13. Depletion rates with infiltration galleries.

\subsection{Design of Infiltration Gallery}

Design of infiltration gallery was carried out through steps explained above. Different parameters used and size of infiltration gallery calculated are shown in Table 4 .

A total of 300 infiltration galleries have been proposed for the recharge of the research area. Total area of research was divided into 2.5 ha and then for reach area the infiltration gallery was designed. The size of the infiltration gallery was used in the Visual MODFLOW software to study its impact on the groundwater levels for the future years. Total land of study area is $\mathbf{5 9 2}$ ha. The division of land is shown in Table 4. The total area required for the 300 infiltration galleries is 10.1 ha. Expected annual recharge volume of water through these infiltration galleries will be $2,467,400 \mathrm{~m}^{3}$.

Table 4. Parameter/design values of infiltration gallery.

\begin{tabular}{lll}
\hline S. No. & Description & Value \\
\hline 1 & Catchment area & $1.31 \mathrm{ha}$ \\
2 & Storage Co-efficient, $C s$ & 0.7 \\
3 & Runoff Co-efficient, $C r$ & 0.4 \\
4 & Rainfall Intensity, $I$ & $16.4 \mathrm{~mm} / \mathrm{hr}$ \\
5 & Volume of Rainfall, $Q p$ & $24.03 \mathrm{~m}^{3} / \mathrm{day}$ \\
6 & Percolation rate, $P$ & $20 \mathrm{~mm} / \mathrm{hr}$ \\
7 & Void Space, $n$ & 0.4 \\
8 & Retention time, $t$ & $16 \mathrm{hr}$ \\
9 & Depth of Trench, $D$ & $2 \mathrm{~m}$ \\
10 & Infiltration Gallery Area, $A$ & $2650 \mathrm{~m}^{2}$ \\
11 & Bed Width, $B$ & $6 \mathrm{~m}$ \\
12 & Length, $L$ & $40 \mathrm{~m}$ \\
13 & Size of Infiltration Gallery & $40 \times 6 \times 2 \mathrm{~m}$ \\
\hline
\end{tabular}

Simple gravel type of infiltration gallery was designed and proposed. Atlantis Leach System has good infiltration rates then simple gavel gallery [5] but due to its construction cost, availability of material, operation and maintenance it was not considered for the current study.

\subsection{Future Depletion Rate of Groundwater with Infiltration Galleries}

Infiltration galleries were then added in the groundwater model prepared on Visual MODFLOW. For this case two layers of the model were added. The depth of the first layer was up to the depth of infiltration gallery while the depth of the second layer was equal to the depth of the aquifer of Lahore. The layer properties were added in the model just as done for the single layer model. The model was then run for next five years and the groundwater depletion rates were estimated with the presence of infiltration galleries in the model. The results showed that when the infiltration galleries are being placed in the model, for the recharging than the depletion rate reduces to $0.8-0.85$ meters for the next five years. The results depicted that with the installation of infiltration galleries the depletion rate is reduced and these are helpful for the recharge of the groundwater aquifer.

As according to [1] the Infiltration Trench prevented runoff, same is the case in this study that it would also reduce the flooding in the study area. Majority of the rainfall in Lahore occurs in monsoon season (June to September), so proper maintenance of the infiltration galleries is required during these months.

\section{Conclusions}

Water table decline rate ranges from 0.8 to $1.1 \mathrm{~m}$ per year in the study area in the year 2018. The average water table decline rate is $0.95 \mathrm{~m} /$ year. Visual MODFLOW was well 
calibrated and validated for the study area as results were found in $95 \%$ confidence interval. Groundwater depletion rates in the study area without infiltration galleries for next 5 years were assessed as $1.1 \mathrm{~m} /$ year. Groundwater depletion rate in the study area with infiltration galleries was assessed as $0.8 \mathrm{~m} /$ year. Study shows that groundwater depletion rate has reduced due to the installation of infiltration galleries in the study area. Average reduction in groundwater depletion rate is about $0.15 \mathrm{~m} /$ year. Provided number and lengths could not support the sustainable groundwater abstraction rates.

\section{Recommendations}

\subsection{Based on the Findings}

Infiltration galleries are recommended to reduce the groundwater depletion rates in the study area.

\subsection{Based on the Future Directions}

LDA policy for provision of groundwater recharging facilities for housing societies and parks should be strictly implemented. New housing societies in the city must follow their allocated groundwater extraction quota to avoid the over extraction and this quota must be fixed depending on specified per capita requirement. They must develop a sustainable groundwater system which balances the amount of abstraction and recharging. To increase recharge to groundwater, green environmental friendly techniques such as infiltration galleries, green parking and concept of rainwater harvesting must be implemented in all residential societies.

\section{References}

[1] Anna Petit Boix, Eva Sevigne-I., Lorena A. R. Gutierrez, Ademir P. Barbassa, Alejandro J., Xavier Gabarrell, 2015. Environmental and economic assessment of a pilot stormwater infiltration system for flood prevention in Brazil, pp. 194-201.

[2] Bhagu Ram Chahar, Didier Graillot, Shishir Gaur (2012), Storm-water management through Infiltration trenches, Journal of Irrigation and Drainage Engineering, American Society of Civil Engineers, pp. 274-281.

[3] Census 2017, Pakistan Bureau of Statistics. http://www.pbs.gov.pk, assessed on 10-10-18.

[4] Department of Ecology, State of Washington, Stormwater Management Manual for Western Washington, 2012, Volume III, pp. 3-96.

[5] Elise Bekele, Simon Toze, Bradley Patterson, Wolfgang Fegg, Mark Shackleton, 2014. Evaluating two infiltration gallery designs for managed aquifer recharge using secondary treated wastewater, Journal of Environment Management, pp. 115-120.
[6] IDEQ (2005), Idaho Department of Environmental, Storm Water Best Management Practices Catalog.

[7] Khubaib Irshad, 2018. Analysis of Ground Water Depletion and its Impact on Water Quality in Lahore, MSc. Thesis UET Lahore, pp. 71.

[8] Laura Toran, Catherine Jedrzejczyk, 2017. Water Level Monitoring to Assess the Effectiveness of Stormwater Infiltration Trenches, Environmental \& Engineering Geoscience, Vol. XXIII, No. 2, pp. 113-123.

[9] LDA (2019), LDA Building and Zoning Regulations, Lahore Development Authority, pp 42.

[10] L. Yesodha, T. Meenambal, KR. Manikandan, 2015. Design of Storm Water Drainage System to Enhance Groundwater Level - A Case Study on Hosur Inner Ring Road (IRR), Bonfring International Journal of Industrial Engineering and Management Science, Vol. 5, pp. 194-201. pp. 100-110.

[11] Melo de Anjos Tenório dos Tássia et al., 2016. Infiltration trench as compensatory technique for urban stormwater management, pp. 53-72.

[12] More Avinash Arjun, (2012). Analysis of Flow through Infiltration Gallery, Department of Civil Engineering, Indian Institute of Technology Roorkee-247667, India, pp. 66.

[13] Muhammad Afzal, 2013. Groundwater Modeling of Lahore using MODFLOW, MSc Thesis UET Lahore, pp. 114.

[14] M. K. Daud, Muhammad Nafees, Shafaqat Ali, Muhammad Rizwan, Raees Ahmad Bajwa, Muhammad Bilal Shakoor, Muhammad Umair Arshad, Shahzad Ali Shahid Chatha, Farah Deeba, Waheed Murad, Ijaz Malook, and Shui Jin Zhu, 2017. Drinking Water Quality Status and Contamination in Pakistan. Hindawi BioMed Research International Volume 2017, Article ID 7908183, 18 pages.

[15] S. A. Lucas and P. J. Coombes 2009, The Performance of Infiltration Trenches Constructed to Manage Stormwater Runoff from an Existing Urbanised Catchment, 32nd Hydrology and Water Resources Symposium, Newcastle Australia.

[16] S. Kanwal, H. F. Gabriel, K. Mahmood, R. Ali, A. Haidar, T. Tehseen, 2015. Lahore's Groundwater Depletion-A Review of the Aquifer Susceptibility to Degradation and its Consequences, pp 26-38.

[17] S. T. Wahab, R. Mamtaz, M. M. Islam., 2016. Applicability of water sensitive Urban Design (WSUD) in Dhaka city, Proceedings of the 3rd International Conference on Civil Engineering for Sustainable Development, KUET, Bangladesh, pp. 24-33.

[18] US Army Corps of Engineers, Hydrological Modeling System HEC-HMS, Quick Start Guide, July 2015.

[19] Victor M. Heilweil, Jerome Benoit, Richard W. Healy, 2015. Variably saturated groundwater modeling for optimizing managed aquifer recharge using trench infiltration, pp. 30103019 . 